レーヨンの繊 維 状莋化法

\title{
（I）前処理条件と反応性について
}

$$
\text { 東邦レーシン株式会社 斎 藤 正 雄・笠 井忠夫 }
$$

\section{FIBROUS ACETYLATION OF RAYON (I)}

By Masao Saitō and Tadao Kasai

(Research Institute, Toho Rayon Co. Ltd., Kitajima-cho, Itano-gun, Tokushima Prefecture, Japan)

A new pretreating process for acetylating rayon in fibrous form was developed. This process comprises three steps, as shown below.

At the lst step rayon is steeped in concentrated potassium acetate aqueous solution ond squeezed ; at the 2 nd step the impregnated rayon is completely dried at about $80^{\circ} \mathrm{C}$ for $2 \mathrm{hrs}$ : and at the $3 \mathrm{rd}$ and last step the dried rayon is washed with acetic acid at room temperature for $2 \mathrm{hr}$. and then lightly squeezed.

The rayon that has passed through this process has a high acetic acid swelling, and at the same time is greatly activated toward acetylation without any loss of strength. Although potassium or sodium salts of weak organic acids, potassium or sodium hydroxide, amines, etc. can be used as impregnant, potassium acetate is thought to be the best.

Reactivity of rayons depends on their acetic acid swelling as well as on kinds of rayon. The more a kind of rayon increases in its acetic acid swelling, the more active the rayon gets toward acetylation, while another kind of rayon often shows a greater reactivity at the same acetic acid swelling than the former. Some of polynosic fibers, which were thought to be less accessible than high tenacity rayon, show a greater acetylation rate than the latter. Heat-treated high tenactiy rayon has the lowest rate of all rayons tested.

(Received October 13, 1962)

\section{1. 緒言}

セルロース繊維を酢化するにはあらかじあ前処理を 行なつて織維へ酿化戍が容易に渗透してゆくよらにしな ければならない。

天然セルロース緎維は，隶眽酸（少量の水を含它眽酸 は更に効果的）によつて前処理効果を与えられる文が， レーヨンの氷酷酸前処理は全く効果がない。桜田らは、, レーヨンをあらかしめ水に浸せきして膨潤させ，これと

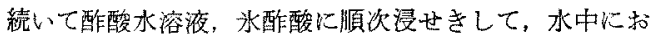
けるレーヨンの膨潤状熊をできるだけ保らながら，その

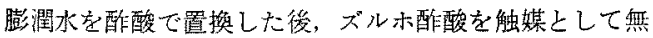

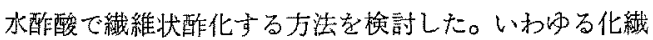
式酢化法と呼ばれているのがこの力法である。前処理に 長時間を要するのが，この方法の欠点である。
浸させ，完全に乾懆した後，酢化する万法を検傠してき だ，4)，この酢化法は，前处理が簡単であるが，酸化液 の变質，酢化緎維の白度低下などの問題を含んでいる。 ところで醉酸カリを包含したレーヨンが何故，絶䩙後、

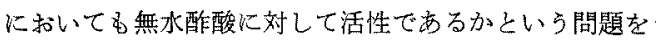
検討した結果，このよらに処理されたレーヨンが，承酢 酸中で大きな膨閏を示すことを見出しだ5。氷酶酸中で このよらに膨閵したレーヨンが，ズルホ酢酸を触禁とす る酢化液中で容易に瀻維状酢化されることも判明した。

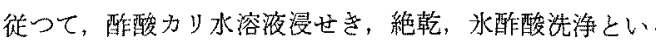
ら一運の処理は, 立派なレーヨンの酭化前処理法といえ るであろら。この前处理の応用は，前記 2 つ酢化法の． 欠点圭除き，その特長を生かした新しい虂維状酢化法を: 提供する。本報に招いては，レーヨンの酷酸膨潤度と酶: 化反応速度の関係を主として報告する。 


\section{2. 実験方法の概要}

\section{1 七ルロース䋐維}

主としてオールスキンタイプの強力レーヨン（当社整 レーコット) を使用与るが，比較のため各種ポリノージ 为維維，木綿 $(2 \% \mathrm{NaOH}$ 水溶液処理済）飞ついて 惨討した。

\section{2 前処 理}

酳酸わリ，酰酸ソーダ，レゾルシンなぞの所定灌度の

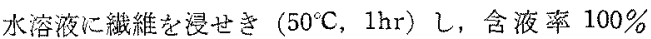
程度までしぼる。水溶液の種類によつては，この程度要 でしばることが圂蜼になるが，その場合は遠心分離機で $500 \mathrm{G}, 10 \mathrm{~min}$ 汪どしばすこととする。次に $80^{\circ} \mathrm{C}$ の電 気乾燥機中で $2 \mathrm{hr}$ 乾燥して水分の汪とんどない状態に 寸る。續いて約 100 倍の兆酶酸に浸也きし，室温で 30 min 洗淨する。水䣷酸を入れかえて，65一度洗浄を 繰返す。これで前処理は終わでり南るが，場合によつて は，アセトン中に投入して繊維中の酢酸をアセトンで置 换萔。

ここで注意すべきことは，酶酸洗浄，アセトン箇換な どの処理後见，䋐倠を強くしばらなよらにすることで 古る。遠心分離機などで強くしばる，前処理效果が極 度に低下する。手で幣くしぼると，含液率約 $300 \%$ にな るが，これ位がよい。な虾「眽酸膨潤度」は，眽酸洗浄

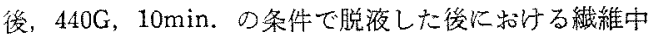
の临酤含有量を示し，次式で定義されるすのである。

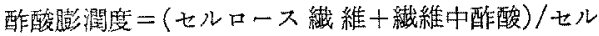
ロ一ス緎維

\section{3 酷 化}

酢化液としては，2種類使用した。

2.3 .1 酶化夜 $[\mathrm{I}]^{2)}$

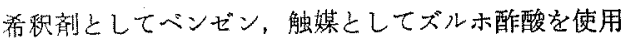
马。

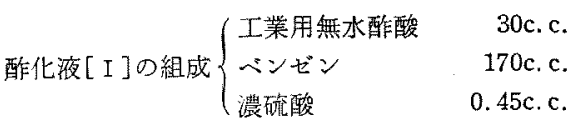

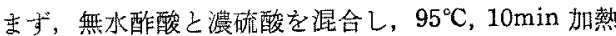

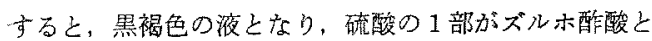
なる。冷却後ベンゼンを加光る。酢化温度は $30^{\circ} \mathrm{C}$ 以下， 溶比 100 倍を標沎とする。

酢化液に，前処理済のレーヨンを投入すると，最初 2 $\sim 3^{\circ} \mathrm{C}$ の温度上年があり，その後次第にレーヨンが膨潤 透明化して，ややだらりとなつてくる。

所定時間反応を行なつてから取出し、アルコール洗浄 水洗，湯洗を行なつて充分酸やベンゼンを除去した後， 畭煰し，常法により眽酸便を涀定する。

\section{3 .2 酢化液 $[$ II $]$}

触媒として硫酸のがわりに酷酸力りを使用し，希鄱剂 社使用しない。

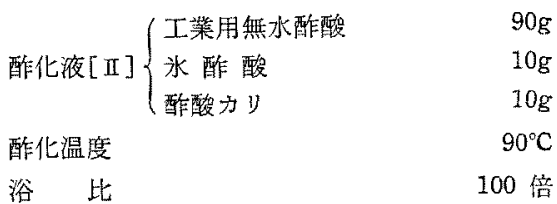

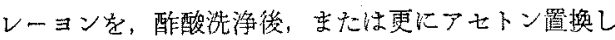
た後に上記酢化液に投入し，酿化する。酶酸カリは，わ ずか不溶で残る。酶化絨維の溶解は全く諗められない。 酶化後の処理は2.3.1 亿同し。

\section{3. 実験結果むよび考察}

\section{1 種々の前処理水溶液の効果}

酶酸カリ，酢酸ソーダ，展素，レゾルシン，へ平サメ キレンジアミンのそれぞれ $40 \%$ の水溶液に浸世諼， 脱液, 乾燥, 酢酸洗浄したオールスキンタイプの強力レ ーヨンの酢酸膨潤度之，ズルホ酢酸を触媒とする酰化液

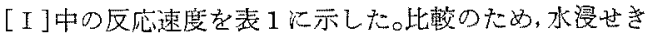

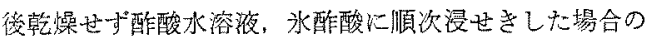
前起理効果学追加した。

6 種の前処理中で，酰酸カり水溶液を使用する前処理 Bが最高の酶酸脚潤度と，同時に最高の酢化反応速度を 示す。前処理中心，乾燥といら七ル口ースの角質化を季 权く可能性の強い処理を含まない前処理 $A$ 上りも效果的 でかる。

婊 1 前処理の種類と酢化反応速度

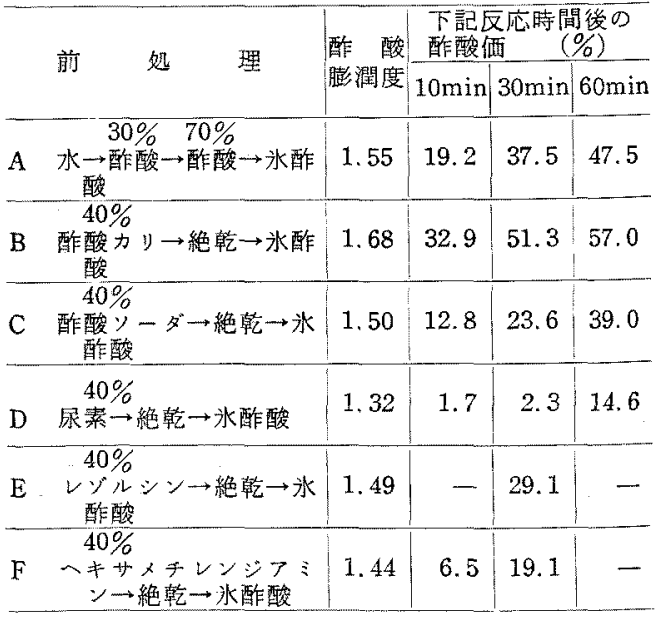

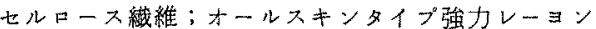

乾䶂; $80^{\circ} \mathrm{C}, 2 \mathrm{hr}$

膨潤度測定；440G，10min 脱液 酶化液；［I] 
前処理效果俚，酶酸カリ，酷酸ソー ダ,レゾルシン, へキサメチレンジア ミン，杘素の順汇悪化する。

レゾルシン水溶液を使用する前题理 Eは表 2 に示すように前処理工程の畭 燥温度吕, 前処理効果佁い影響を与. 克，乾燥温度の上年は，激しい酶酸膨 潤度および反応速度の低下去招く。

乾燥温度が $105^{\circ} \mathrm{C}$ 以上になると、レ 一ヨンは畭燥中に着色し始的, 前処理 効果は，ほとんど失なるれてしまう。 カテコール，ピロガロールすレゾルシ ンの上らな効果を持つが，水に﨎する 溶解度がより小さく、レゾルシン以上 の效果は望めない。

ヘキサメチレンジアミン皮溶液の結 果を表 3 に示した。この場合は乾燥温 度の影筤がさらに激しく，乾燥温度は 50〜60足以下でなければならず，乾燥 は絶渂とまではゆかないこのアミン

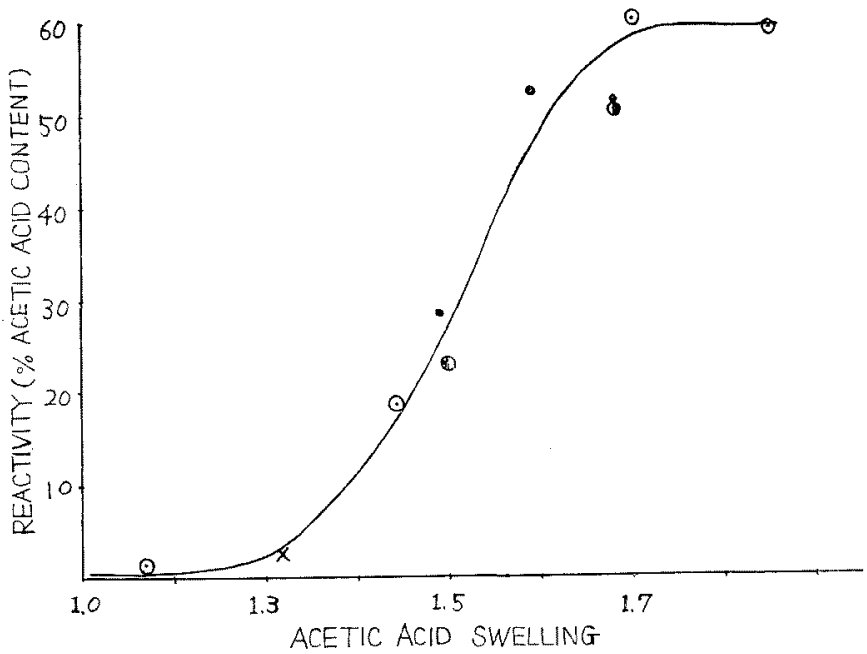

Fig. 1. The relation between acetic acid swelling and reactivity. acetylation: $30^{\circ} \mathrm{C}, 30 \mathrm{~min}$.

impregnants: $\odot$ hexamethylene diamine

resorcinol
は算性ですり，㖕燥中に飛散しやすい。高沸点のアミ ン類，カ性アルカリも効果的である。後者は一般にその 木溶液が强い膨潤作用（特にレーヨンに対し）を持つの で、浸せき中にレーヨンの強度低下が起こる可能性があ るばかりでなく，続く乾燥に拁いて，アルカリセルッ一 スの老成に怙るように, 強度, 重台度の低下が起こり

表 $24 n \%$ レゾルシン水溶液を使用する時の乾 燥温度之前処理协果

\begin{tabular}{|c|c|c|c|}
\hline \multirow{2}{*}{ 乾 燥 架 件 } & \multirow{2}{*}{$\begin{array}{l}\text { 酢 酸 } \\
\text { 膨閪度 }\end{array}$} & \multicolumn{2}{|c|}{ 䣫酸酎 $(\%)$} \\
\hline & & $10 \mathrm{~min}$ & $30 \mathrm{~min}$ \\
\hline $\begin{array}{l}20^{\circ} \mathrm{C}, \mathrm{P}_{2} \mathrm{O}_{5} \text { のもと減生, } \\
20 \mathrm{hr}\end{array}$ & 1.68 & 39.6 & 51.8 \\
\hline $50^{\circ} \mathrm{C}, \quad 4 \mathrm{hr}$ & 1.59 & - & 53.1 \\
\hline $80^{\circ} \mathrm{C}$ & 1. 49 & - & 29.1 \\
\hline $105^{\circ} \mathrm{C}$ & 1.25 & - & - \\
\hline
\end{tabular}

表 $340 \%$ $40 \%$ ヘキレンジアミン水溶液を使用す る時の乾學温度と前処理効果

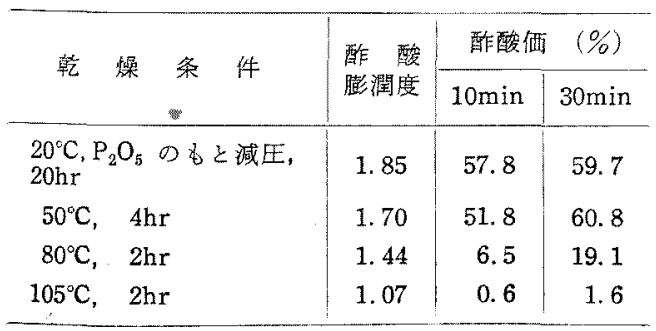

P叶

ところで，酢酸膨潤度と反応性は，前処理試真には無

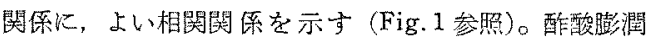
度が 1.3 以下では反応性は不良であるが，1.3 以上にな

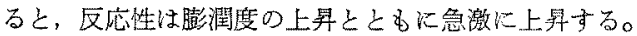
酢酸膨潤度が 1.7 以上になると反応性は䌙ばいになつて いるが，これは，膨潤度 1.7 以上のものは $30 \mathrm{~min}$ 以内 でトリアセテートまで酢化されてしま5からであつて， 膨潤度 1.7 ののと，1.850ものの反応性が同じわけで はない。

\section{2 前処理酰酸力リ水溶液濃度と反応性}

前項において，種々の前処理液について検討したが， 以下に述べるような理由により醀酸カリ水溶液が最も適 当と思われる。この水溶液のレーヨンに対する膨潤作用 は，水のそれと大差なく，レーヨンはこの水溶液に浸せ さしてb，全く機械的強度に变化がない。この溶液を含 んだレーヨンは, $100^{\circ} \mathrm{C}$ 付近の温度で, 機械的強度をそ こならことなく完全に乾噪される。幹燥温度か $100^{\circ} \mathrm{C}$ 以 上になり，乾蜗時間が必要以上に長びくと，レーミンの

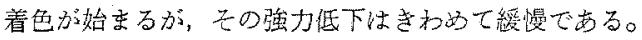

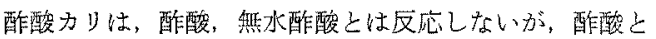
非常に親和性が強く，前処理によつてレーヨン中に抱含 きれて酢酸カリは，酷酸洗浄によつて容易に眽酸中に溶 出し、レーヨンは高い酢酸膨潤度を示す。

そこで醀酸カリ水溶液の效果を少し詩細倹愊してみ た。その結果を表 4 に示す。 


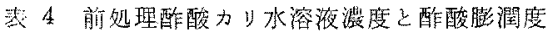
及吸度性

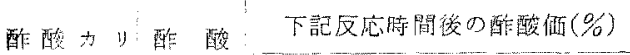

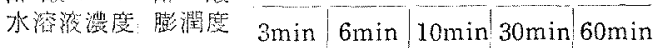

\begin{tabular}{l|l|r|r|r|r|r}
\hline $20 \%$ & 1.40 & - & - & 5.0 & 10.7 & 21.5 \\
40 & 1.68 & - & - & 37.1 & 51.8 & 57.0 \\
60 & 1.85 & - & - & 55.8 & 59.7 & 60.8 \\
70 & 1.89 & 35.6 & 53.5 & 55.7 & - & - \\
80 & 1.88 & 40.2 & 53.5 & 55.8 & - & - \\
\hline
\end{tabular}

酷化液：[I], 酷化温度 : $30^{\circ} \mathrm{C}$

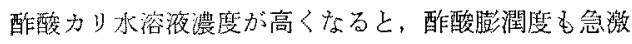
に增大するが，酢酸カリ水溶液渷度が $60 \%$ 以上になる と，配酸膨潤度はほとんど一定になつてしまう。このよ らに酢酸膨潤したレーヨンの酢化液[I]中における酢化 速度は, 10 分酢化後のレーヨンの酷酸価から明らかなよ 5 に，釄酸膨潤度上平行的に变化し，酰酸膨潤度の等し いものは，弫とえど同じ酷化速度を示す。この事器は酢 化液の緎維内浸透が反応の律速段蒈であることを物語る ものと考卡られる。この関係をグラフ化したのが Fig. 2 でする。

桜田らの前処理法によれば,オールスキンタイプの強 カレーヨンは約1.5の酶酸膨 潤度を゙示し，Fig. 2 の酢化条 件 $\left(30^{\circ} \mathrm{C}, 10 \mathrm{~min}\right)$ で醀化する 之，酢酸価 $15 \%$ 前後を示卞 炕過ぎない。

次に，前知理液を変えずに 酷化条件（反応温度，触媒） を変劣た場合について検討し その結果を表 5 に示した。酢 化液［I]のかわりに酥酸力り を触媒とする酢化液[II]を使 用し，反応温度を $30^{\circ} \mathrm{C}$ 火か わつて $90^{\circ} \mathrm{C}$ とた。また酢 酸カりを酶化触媒上するとき は，酡酸が反度速度を激しく 低下させ质 ことがわかつて いるので，前処理で酢酸膨潤 したレーヨンを，酿化前にア セトン中に投入し，酢酸置 換 (窒温, $1 \mathrm{hr}$ ) 七てから酶 化劣ることる試みた。この結 果む表 5 に含ませた。

アセトン犆換しない場合, 酷化速度は，酢酸力リ水溶液
表 5 前処理酶酸カり水溶液濃度と反応性 （酢酸力リ触媒の酷化湤中）

\begin{tabular}{|c|c|c|c|c|c|}
\hline \multirow{2}{*}{$\begin{array}{c}\text { 前処理酷酸力 } \\
\text { 水溶液濃塺 } \\
(\%)\end{array}$} & \multirow{2}{*}{\multicolumn{2}{|c|}{$\begin{array}{l}\text { アヒトン } \\
\text { 蛋 }\end{array}$}} & \multicolumn{3}{|c|}{$\begin{array}{c}\text { 下記反店時間後の酢酸值 } \\
(\%)\end{array}$} \\
\hline & & & $10 \mathrm{~min}$ & $30 \mathrm{~min}$ & $60 \mathrm{~min}$ \\
\hline \multirow{2}{*}{10} & 古 & $b$ & 1.7 & 8.7 & 13. 5 \\
\hline & $な$ & L & 3.4 & 9.9 & 12.5 \\
\hline \multirow{2}{*}{20} & 古 & b) & 16.1 & 28.2 & 29.5 \\
\hline & な & L & 12.9 & 24.5 & 31.9 \\
\hline \multirow{2}{*}{30} & 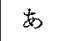 & $\eta$ & 39.9 & 46. 9 & 52.4 \\
\hline & $な$ & $L$ & 23.6 & 34.9 & 43.9 \\
\hline \multirow{2}{*}{40} & 㫣 & b & 41.3 & 47.9 & 52.8 \\
\hline & & L & 28.6 & 41.9 & 49.1 \\
\hline \multirow{2}{*}{50} & क & $\eta$ & 44.9 & 48.9 & 53.6 \\
\hline & な & $L$ & 35.5 & 45.3 & 51.1 \\
\hline \multirow{2}{*}{60} & $\varpi$ & b & 47.5 & 51.9 & 54.1 \\
\hline & $な$ & L & 40.7 & 50.4 & 53.5 \\
\hline \multirow{2}{*}{70} & 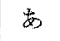 & $\eta$ & 45.8 & 53.1 & 53.9 \\
\hline & な & L & - & 47.7 & 53.5 \\
\hline 酢化液 [ II] & $\begin{array}{l}\text { 無水 } \\
\text { 醀 } \\
\text { 酢酸 }\end{array}$ & $\begin{array}{l}\text { 酸酸 } \\
\text { 酸 } \\
\text { 力 } 1\end{array}$ & $\begin{array}{l}85 g \\
15 g \\
10 g\end{array}$ & 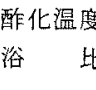 & $\begin{array}{r}90^{\circ} \mathrm{C} \\
100 \text { 倍 }\end{array}$ \\
\hline
\end{tabular}

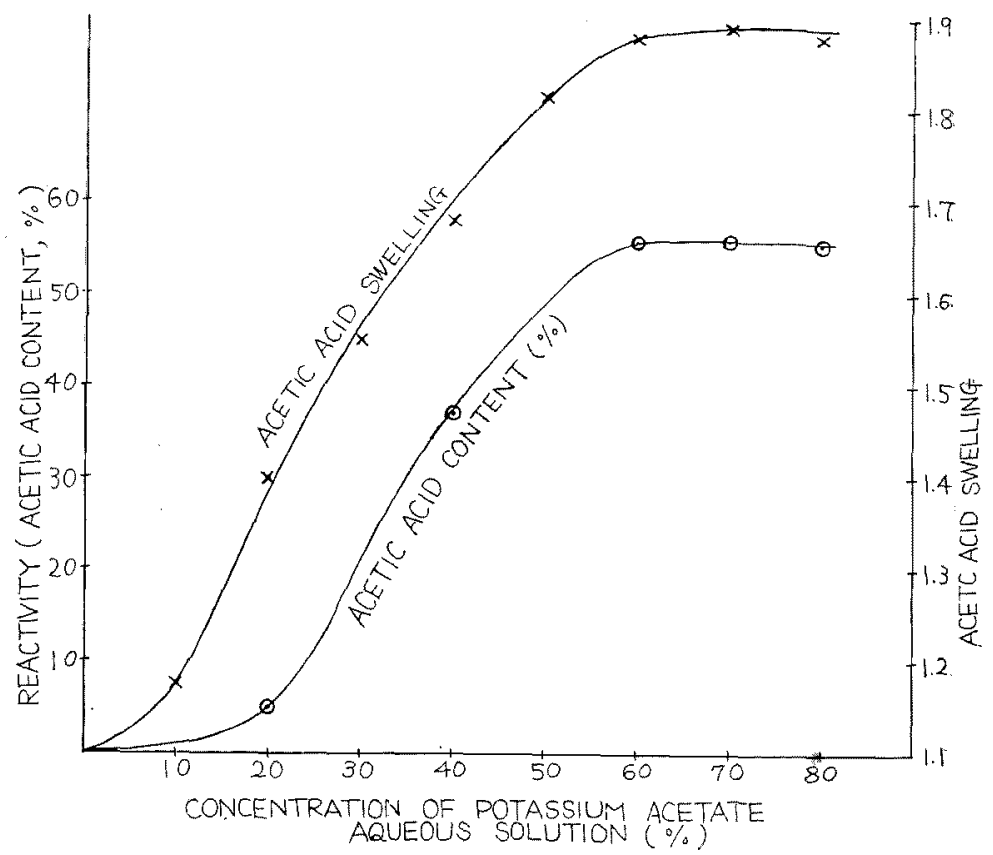

Fig. 2. Reactivity and acetic acid swelling of high tenacity rayon versus concentration of pretreating potassium acetate aqueous solution. acetylating liquid: acetic anhydride $30 \mathrm{cc}$. benzene $170 \mathrm{cc}$. sulphuric acid $0.45 \mathrm{cc}$ acetylating time and temperature : $10 \mathrm{~min}, 30^{\circ} \mathrm{C}$ 
浀度の增加とともに增大する。しかるにアセトン固换し た場合は，前者上り反応速度が速く，その反応速度は，

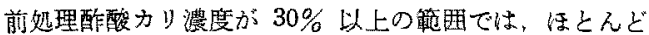
一定になつている。これらの場合, 反沈温度が $90^{\circ} \mathrm{C} て ゙$ あるから，前に述べた酢酸膨澗度（室温で則定された） は，反応中のレーヨン䐆潤状態の直接の目安とはなり得 ない。レーヨンは酢化反応によつてさらに膨潤しようと すると同時に，高温にさらされて角筫化し脱膨潤を起こ そらとする。レーヨンに含浸された液の種類によつて も，角質化速度は変わつてくるであるう。われわれの経 験によれば、含漫液の酸性の強さ，親本性等が角質化速 度にかなり強い影響を与えるようである。アセトン置捽 したすのは角質化されにくく䤏化液の渗透がより速く， 酢化速度が高くなるものと考觉る。

\section{3 酶酸カリ水溶液を使う前処理法における乾燥温 度と酢酸洗浄温度の影響}

$40 \%$ 酰酸力リ水溶液を使与場合，前処理工程中の乾燥

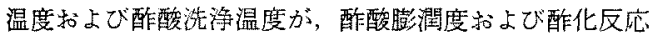
性に心よばす影響を調べた。Fig.3には，乾燥温度を一 定 $\left(80^{\circ} \mathrm{C}\right)$ にして，眽酸洗浮温度を变えた $\left(30 \sim 90^{\circ} \mathrm{C}\right)$

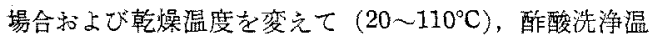
度を一定 $\left(30^{\circ} \mathrm{C}\right)$ にした場合の酢酸膨潤度の変化を示し た。乾燥温度が $20 \sim 80^{\circ} \mathrm{C}$ の範囲では，酢酸膨潤度はは

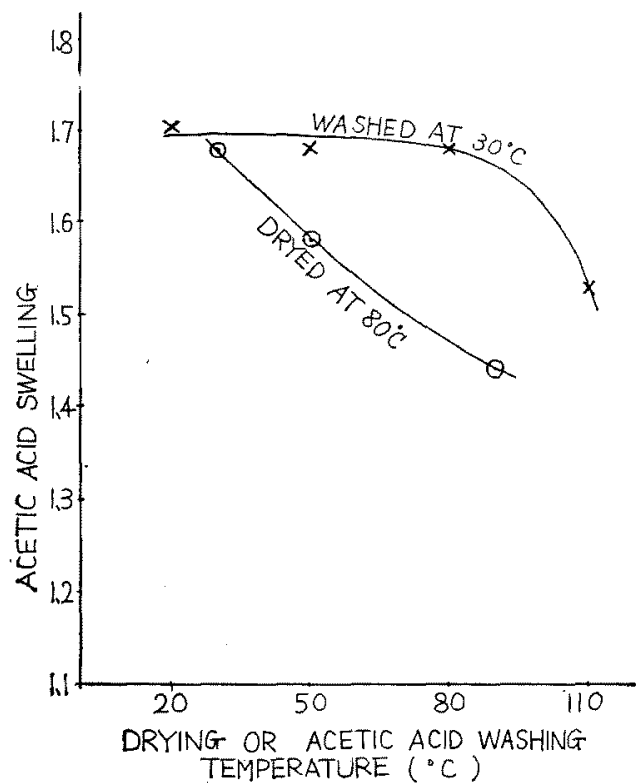

Fig. 3. Effects of drying and acetic acid washing temperature on acetic acid swelling of rayon, impregnated with $40 \%$ potassium acetate.
表 6 眽酸洗浄温度と酢酸膨潤度於よび反応性

\begin{tabular}{|c|c|c|c|c|}
\hline \multirow{2}{*}{ 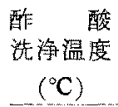 } & \multirow{2}{*}{$\begin{array}{l}\text { 酢 酸 } \\
\text { 膨溜度 }\end{array}$} & \multicolumn{3}{|c|}{ 下記反他眭間啳の酢酸価（\%） } \\
\hline & & $10 \mathrm{~min}$ & $30 \mathrm{~min}$ & $60 \mathrm{~min}$ \\
\hline 30 & 1.68 & 34.1 & 50.5 & 59.4 \\
\hline 50 & 1. 58 & 27.0 & 42,9 & 56.0 \\
\hline 90 & 1. 44 & 17.8 & 38.1 & 55.5 \\
\hline
\end{tabular}

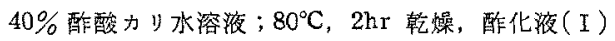

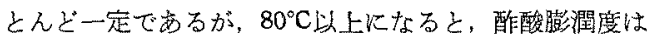
かなり低下する傾向にある。これに対し，酢酸洗浮温度 が上界すると $\left(30 \sim 90^{\circ} \mathrm{C}\right.$ の範团でも), 酰酸膨潤度は直 線的に低下する。酷酸膨膶度に対し酢酸洗浄温度のは が乾燥温度よりはるか強い影響力を示す。この事実は 酢酸カリがレーヨン中に合まれているときには，温度が 高くなつてもレーヨンの角筫化は起こりにくいが，酢酸

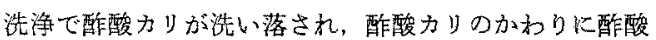
が入ると，非常に角質化しやすくなることを物語るもの と思われる。

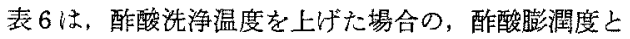
反応性を示すものである。酶酸洗浄温度の上䄯で，酢酸 橵潤度が低下し，反迌速度も低下する傾向にはあるが， 同一の酢酸膨潤度のものの反応性を Fig. 1 や.Fig. $2 の$ データと比較すると，この表の結果のほらが良好な反応 性を示している。この理由は明らかでない。

\section{4 各種セルロース緎維の反㤁性}

以上は，オールスキンタイプの強力レーヨンKついて

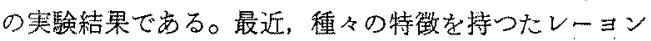
の生産が各社で始められたのでここれらレーヨンに本前 如理法を適用し，その反応性を検討した。結果を表 7 に 香した。

レーコット（オールスキン型強力レーヨン）, トービ

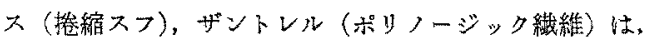
上く似た反応性を示すが，酶酸膨潤度は，1.68，1.83， 1.65 となつて和り，やや差がある。－61，ハイポラン， メリル（いずれるポりノージック瀻維）恃に反応性が 良好で，M-61，メリルは容易にトリアセテートになる。 結晶領域も，ほとんど，酢化反応に抵抗しない上うにみ える。䣫酸瞦潤度はそれぞれ，1.73，1.71，1.83となつ でり、特に高、値ではない。これらのレーヨンは，レ ーヨンの中では結晶性が高く，木綿似似た性質を示し，

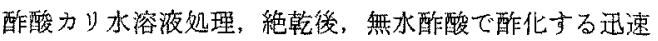
酢化法3),4)では，最も反応性が悪いものである(表 8 参 照)。

アブリル（ポリノージック絨維）は特に反応性が悪く， 緊張水蒸気処理 $\left(9.2 \mathrm{~kg} / \mathrm{cm}^{2}\right.$ の蒸気にて $\left.23 \mathrm{sec}\right)$ したレ 


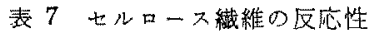

\begin{tabular}{|c|c|c|c|c|}
\hline \multirow{2}{*}{ ヒルロース乘維 } & \multirow{2}{*}{$\begin{array}{l}\text { 酢 酸 } \\
\text { 㱶潤度 }\end{array}$} & \multicolumn{3}{|c|}{ 䣫 酸 洒 $(\%)$} \\
\hline & & $10 \mathrm{~min}$ & $30 \mathrm{~min}$ & $60 \mathrm{~min}$ \\
\hline$\checkmark-ב \% R$ & 1.68 & 37.1 & 51.8 & 57.0 \\
\hline$V-J \geqslant r^{* 1}$ & - & 40.3 & 56.8 & 一 \\
\hline 熱処 理 $レ ー \Xi ッ ト * 2$ & 1.61 & 12.0 & 25.7 & 32.0 \\
\hline 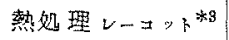 & 1.68 & 46.6 & 59.8 & - \\
\hline$N-\varepsilon \pi$ & 1.83 & 41.9 & 52.1 & 59.5 \\
\hline$M-61 * 4$ & 1.73 & 54.3 & 59.6 & 60.4 \\
\hline $7 \quad 7 \quad y$ & 1.72 & 16.7 & 29.8 & 49.5 \\
\hline ザントレル & 1.65 & 35.9 & 53.4 & 59.9 \\
\hline ル & 1.83 & 55.8 & 60.6 & 一 \\
\hline 八1 & 1.71 & 55.6 & 56.2 & 57.0 \\
\hline 木 & 1.58 & 23.8 & 32.2 & 38.1 \\
\hline
\end{tabular}

前処理液: $40 \%$ 酿酸力》水溶液

醀化液 ( I )

*I) $5 \% \mathrm{NaOH}$ 水溶淮処理（室温，60min）したもの

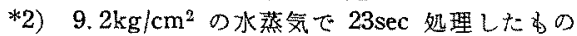

*3) 熱処理後更飞 $5 \% \mathrm{NaOH}$ 水溶液処理（室温，60 min) した。の

*4) 当社诫リノーショク瀻維の仮名

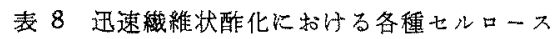
䋊維の反応性

\begin{tabular}{|c|c|c|c|c|}
\hline \multirow{2}{*}{ セルロース瀻維 } & \multicolumn{3}{|c|}{ 下記反広時間後の酷酸优 } & $(\%)$ \\
\hline & $20 \mathrm{sec}$ & $40 \mathrm{sec}$ & $60 \mathrm{sec}$ & $90 \mathrm{sec}$ \\
\hline$v-z ッ r$ & 35.2 & 45.0 & 48.5 & 48.9 \\
\hline 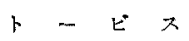 & 36.4 & 43.4 & 48.5 & 49.0 \\
\hline$M-61$ & 11.9 & 37.4 & 40.1 & 45.5 \\
\hline$ア フ ゙$ & 12.9 & 41.2 & 43.6 & 48.8 \\
\hline ザントレル & 13. 4 & 36.5 & 40.7 & 48.8 \\
\hline ハイ格ラン & 18.3 & 41.7 & 46.3 & 48.9 \\
\hline ヘンヘルク & 34.3 & 40.7 & 42.5 & 43.7 \\
\hline 木 綿 & 11.9 & 14.2 & 14.7 & 14.8 \\
\hline
\end{tabular}

前処理：40\%酷酸力y水溶液漫せき絶乾 $\left(80^{\circ} \mathrm{C}, 2 \mathrm{hr}\right)$ 酿化液: 無水酢酸 $100 \mathrm{c} . \mathrm{c} .+$ 灯油 $100 \mathrm{c} . \mathrm{c}$. 酷酸力 1) $5 \mathrm{~g}$

酷化温度: $120^{\circ} \mathrm{C}$

ーコットと似ている。蒸気处理レーコットは，5\%力性 ソーダ浴液で処理（室温, 60min) ずると, 伸度が增し, 反底性は未処理レーコットよりよくなる。

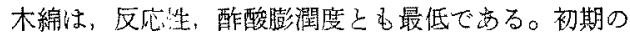
急激な反店の後心徐々に反心する部分は，結晶領域が 応しているるの上思われる。この事寒は，木綿の結晶が レーヨンのそれに比較していかに強固でするかといらこ とを示爫のである。
表 9 酢酸洗浄後の脱液条件と区応性

\begin{tabular}{|c|c|c|c|c|}
\hline \multirow{2}{*}{$\begin{array}{l}\text { 酰酸洗浄後の } \\
\text { 脱液 条件 }\end{array}$} & \multicolumn{2}{|c|}{$M-61$} & \multicolumn{2}{|c|}{$v-=ッ ト$} \\
\hline & 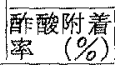 & $\begin{array}{c}\text { 酿酸拪 } \\
(\%)\end{array}$ & 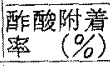 & $\begin{array}{l}\text { 酷酸何 } \\
(\%)\end{array}$ \\
\hline 手し注り & 313 & 51.7 & 307 & 30.9 \\
\hline 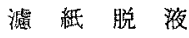 & 180 & 44.9 & 205 & 19.4 \\
\hline $28 \mathrm{G}, 10 \mathrm{~min}$ & 116 & 39.8 & 92 & 19.3 \\
\hline $110 \mathrm{G}, 10 \mathrm{~min}$ & 89 & 44.2 & 74 & 20.3 \\
\hline $440 \mathrm{G}, 10 \mathrm{~min}$ & 73 & 46.0 & 64 & 24.2 \\
\hline $1000 \mathrm{G}, 10 \mathrm{~min}$ & 71 & 41.5 & 56 & 22.6 \\
\hline $1800 \mathrm{G}, 10 \mathrm{~min}$ & 67 & 41.0 & 53 & 22.4 \\
\hline
\end{tabular}

酷化液 (I)

酷化温度衿よび時間: $30^{\circ} \mathrm{C}, 10 \mathrm{~min}$

以上のよらに，各種レ一ヨンの反応性は全くまらまち で, 結晶化度, ラテラルオーダー, 酶酸膨潤度のいずれ をるつてしてる，反枪性を完全に説明することはできな い。ポリノージック䋐維は土オールスキンタイプの強力 レーョンより放射線ダラフトしやすい7といら事実は, この酢化反応性と一致する面があり，興味梁い。虑木綿， 七はファンなどの反応性る考台合わせてみると，ビスコ 一スの再生浴中の硫酸理鉛の濃度とレーヨンの反応性が かなり密接な関係を持つよらな気がするので，さらに检 討したいと考觉ている。

\section{5 酢酸洗浄後の脱液条件亡反応性}

以上の実験では，酶酸洗浄後，手でかるるしばつて酢 酸付着率 300\% 程度にし, 酷化液 [I]で醀化するの常 とした。酶化液投入前の酢酸付着率は，非常に反応性に 影響㧍るといわれているので，脱液条件之酢酸付着率お よび反応性との関係を検討し，表 9 亿示した。

醀酸付着率が $300 \%$ から $200 \%$ に低下す吕と，急に 反応性が悪化するが，酢酸付着率が $200 \%$ 以下ては，汪 とんど反瓜性に差は認められない。レーュットと M-61

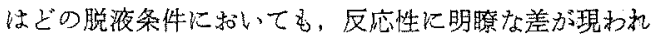
ている。

\section{3. 総 括}

1) レーヨン瀻維状酢化の前処理法として下記の処理 法索示した。

第1 工程 高濃度酢䣲为》水溶液漫世き。

第 2 工程 絶乾。

第 3 工程 水酷酸洗浄。

2）第 1 工程には，酢酸カリ水溶液のかわりに，有機

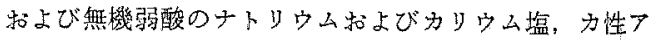
ルカリ，レゾルシン，高娜点のアミン類などの水溶液が 使用できるが，総合的比判断すると，酭酸カリ水溶液が 最良で方。 
3) 第 2 の乾燥工程では，乾燥温度が $80^{\circ} \mathrm{C}$ 付近か元 れ以下であることが望ましい。乾燥温度があ委り高くな ると，前処理效果が低下するからである。

4) 第 3 の酶酸洗浄工程は，できるだけ低温で行なら ことが望京しい。酢酸洗浄温度の低い汪ど，高い酶酸膨 潤度が得られる。尗た，前処理後の脱液で，酶酸付着率 が 200\% 以下になると，反応速度が急见低下寸るので注 意を要する。

5）この前处理を受けたレーヨンは，ズルホ酶酸を触 媒とする䣫化液中で, 容易に酢化さ扎る。同一種のレー ヨンでは，酢化速度と前处理後の酷酸膨潤度は平行的な 関係に市る。

6）酷化速度は，レーヨンの種類により非常に差があ る。ポリノージック繊維化属する M-61, ×リル, メイ
ポランは非常に反応性がよく、レーコット，トービス， ザントレルが中間的反応性を示し，熱処理レーコット， アブリルは非常に反応性が悪い。

付記 終始ご指導下さいました研究所長 楠瀬正致氏 室長永井一弘博士，研究員佐治安夫氏に深く感謝する。

\section{文献}

1) 木戸，鈴木，林；緎学誌，18，557 (1962)

2）桜田；人絹界，9，110，168（昭 16）

3) 永井, 寗藤；緎学誌, 18, 874 (1962)

4) 斎藤, 笠井, 永井; 同上，18，378（1962）

5) 紊藤, 笠井, 永井; 同上投稿中

6) R. C. Blume, F. H. Swezey ; Tappi, 37, 481 (1954)

7）香山；私信 